\title{
MODELING OF PROPERTIES OF FIBER REINFORCED CEMENT COMPOSITES
}

\author{
$U D C 69.54(045)=111$
}

\section{Dragica Jevtić, Dimitrije Zakić, Aleksandar Savić}

University of Belgrade, Faculty of Civil Engineering, Serbia

\begin{abstract}
This paper presents the results of authors' laboratory testing of the influence of steel fibers as fiber reinforcement on the change of properties of cement composite mortar and concrete type materials. Mixtures adopted - compositions of mortars had identical amounts of components: cement, sand and silica fume. The second type of mortar contained $60 \mathrm{~kg} / \mathrm{m}^{3}$ of fiber reinforcement, as well as the addition of the latest generation of superplasticizer. Physical and mechanical properties of fiber reinforced mortars and etalon mixtures (density, flexural strength, compressive strength) were compared. Tests on concrete type cement composites included: density, mechanical strengths and the deformation properties. The tests showed an improvement in the properties of fiber reinforced composites.
\end{abstract}

Key words: Composite, Mortar, Concrete, Steel Fibers, Silica Fume, Mechanical Strenght, Deformation Properties

\section{INTRODUCTION}

Contemporary Civil engineering is permanently setting new conditions concerning the quality of engineering materials. These conditions have to be completely fulfilled in order to increase the durability, serviceability and cost-effectiveness of modern buildings. The composite materials, which will be the main subject of this paper, are offering great possibilities in the field of research and combination of more advanced solutions in order to keep up with contemporary trends.

Fiber reinforced cement (FRC) composite materials are basically mortar and concrete composites made with addition of different types of fibers which represent a special micro-reinforcement. Uniformly dispersed fibers are strengthening the cement matrix, thus improving the whole set of properties of the basic material. The cement matrix, as the base, can be reinforced using metalic (steel), synthetic (polymeric), ceramic (glass), or natural (organic) fibers.

Essentialy, the fiber-reinforcement concept is about the increment of quality of a complex composite material (mortar and concrete) by improving certain properties of fresh and hardened material which are crucial for its practical application. The best effects are achieved in the field of strength improvement (especially in flexure, tension and shear) as well as in ductility 
increment of the above mentioned composites. Also, good results are obtained concerning the reduction of shrinkage, as well as the improvement of fatigue and impact resistance behavior.

\section{EXPERIMENTAL RESULTS}

\subsection{Research on mortar composites}

This paper represents the results of own experimental research, conducted in the Laboratory for Materials, Institute for Materials and Structures, Faculty of Civil Engineering, University of Belgrade, on two types of mortar - cementitious composites. In fact, the paper compares the reference mortar mixture (marked as "E") made without the addition of fibers and fiber-reinforced mortar (marked as "V") with steel fibers added. Experimental studies of mechanical strength (flexural strength and compressive strength), which are the subject of this paper, were conducted on these mortar composites.

Adopted mixture compositions, i.e. contents of mortar "E" (reference mixture) and mortar "V" (fiber-reinforced mortar) were identical with regard to the amounts of basic components: cement, sand and silica fume. Fiber-reinforcement $\left(60 \mathrm{~kg} / \mathrm{m}^{3}\right)$ and admixture type superplasticizer were present in the second type of mortar (marked as "V"). The presence of the superplasticizer was needed to achieve the same consistency of this composite and reference mortar mixture. The amount of water in both mortars was adopted to achieve the mortar slump flow of $180 \pm 20 \mathrm{~mm}$.

Cement used in this experimental study was pure Portland cement CEM I 42.5 R produced in Cement Works "Lafarge" Beočin. Standard three-fractional (quartz) sand has been chosen as aggregate for mortars studied in both series. Its fractions (I - 0/0.5 mm, II $0.50 / 1.00 \mathrm{~mm}$ and $\mathrm{III}-1.00 / 2.00 \mathrm{~mm}$ ) were present in mass ratio $1: 1: 1$. Therefore, nominally largest aggregate grain in mixture was $\mathrm{D}=2 \mathrm{~mm}$. Silica fume was present in both series in the amount of $10 \%$ of the cement mass. Admixture type superplasticizer named "Glenium 51", produced by M.A.C. s.p.a., Treviso, Italy, was added in amount of $1 \%$ of the cement mass. This admixture of newer generation is based on carboxylate ethyl polymers with long side chains, which provide sustained consistency for a longer period of time.

Steel fibers used as fiber-reinforcement are locally produced. The manufacturer of the fibers is "Spajić", Kobišnica, Serbia. Adopted fibers are bent on ends (hooked), dimensions $30 \times 0.6 \mathrm{~mm}$, with aspect ratio $1 / \mathrm{d}=50$, in quantity of $60 \mathrm{~kg} / \mathrm{m}^{3}(0.45 \%$ of volume). Basic properties of these fibers are presented in Table 1 and Figure 1 shows the shape of fibers.

Table 1 Basic properties of fibers declared by the manufacturer "Spajić"

\begin{tabular}{|l|c|}
\hline Parameters & Declared Properties \\
\hline Type and shape & Circle \\
Cross section & min. $1100 \mathrm{MPa}$ \\
Tensile strength & app. $1500^{\circ} \mathrm{C}$ \\
Melting point & $\min .45^{\circ}$ \\
Angle of bending & $30 \pm 2 \mathrm{~mm}$ \\
Total length (A) & $0.6 \pm 0.1 \mathrm{~mm}$ \\
Thickness (E) & $20 \pm 1 \mathrm{~mm}$ \\
Length of unbent part (B) & $4.5 \pm 1 \mathrm{~mm}$ \\
Length of bent part (C) & \\
\hline
\end{tabular}




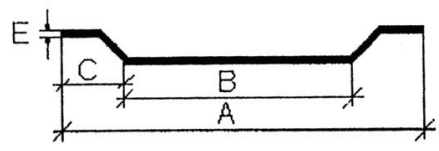

Fig. 1 The shape of fibers used as fiber-reinforcement

In order to examine the mortar properties, 15 prismatic $(4 \times 4 \times 16 \mathrm{~cm})$ specimens were made of each composite type. Specimens were cured in a mold and in humid environment for the first 24 hours, and afterward, until the day of examination, constantly in water. Comparative examinations were conducted on fresh mortar (density measurement) and on hardened mortar (measurement of flexural and compressive strength) after 2, 4, 7, 28 and 90 days. The average values of the three measurements for each type of mortar have been represented in Table 2. as well as on Fig. 2, 3 and 4.

Table 2 Overview of physical and mechanical properties of the tested mortars

\begin{tabular}{|c|c|c|c|c|c|c|c|c|}
\hline \multirow{2}{*}{$\begin{array}{l}\text { Age } \\
\text { (days) }\end{array}$} & \multicolumn{2}{|c|}{$\begin{array}{l}\text { Density } \\
\left(\mathrm{kg} / \mathrm{m}^{3}\right)\end{array}$} & \multicolumn{2}{|c|}{$\begin{array}{l}\text { Flex.strength } \\
\qquad(\mathrm{MPa})\end{array}$} & \multirow{2}{*}{$\begin{array}{c}\text { Increment } \\
\text { (compared } \\
\text { to refer.) } \\
(\%)\end{array}$} & \multicolumn{2}{|c|}{$\begin{array}{c}\text { Comp.strength } \\
(\mathrm{MPa})\end{array}$} & \multirow{2}{*}{$\begin{array}{l}\text { Increment } \\
\text { (compared to } \\
\text { refer.) } \\
(\%)\end{array}$} \\
\hline & $\begin{array}{l}\text { Series } \\
\text { "V" }\end{array}$ & $\begin{array}{l}\text { Series } \\
\text { "E" }\end{array}$ & $\begin{array}{l}\text { Series } \\
\text { "V" }\end{array}$ & $\begin{array}{l}\text { Series } \\
\text { "E" }\end{array}$ & & $\begin{array}{l}\text { Series } \\
\text { "V" }\end{array}$ & $\begin{array}{l}\text { Series } \\
\text { "E" }\end{array}$ & \\
\hline 2 & 2290 & 2143 & 4,5 & 3,4 & 32,35 & 24,5 & 21 & 16,66 \\
\hline 4 & 2278 & 2135 & 7,9 & 5,0 & 58,00 & 38,2 & 29 & 31,17 \\
\hline 7 & 2265 & 2130 & 8,9 & 6,0 & 48,33 & 46,3 & 34 & 36,17 \\
\hline 28 & 2251 & 2090 & 9,5 & 6,65 & 42,86 & 68,5 & 53 & 29,25 \\
\hline 90 & 2244 & 2082 & 9,8 & 7,3 & 34,25 & 85,3 & 66 & 29,24 \\
\hline
\end{tabular}

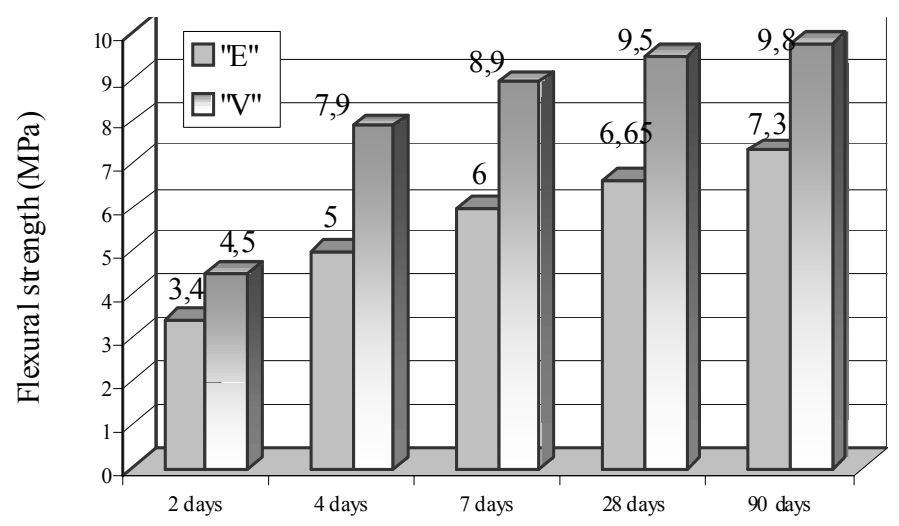

Fig. 2 Comparative review of flexural strength on both series "E" and "V" 


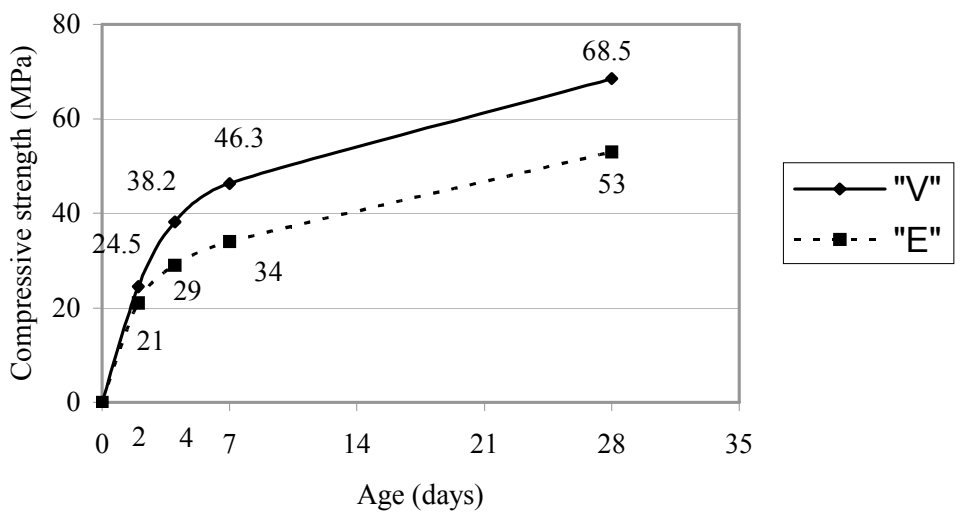

Fig. 3 Compressive strength growth in time

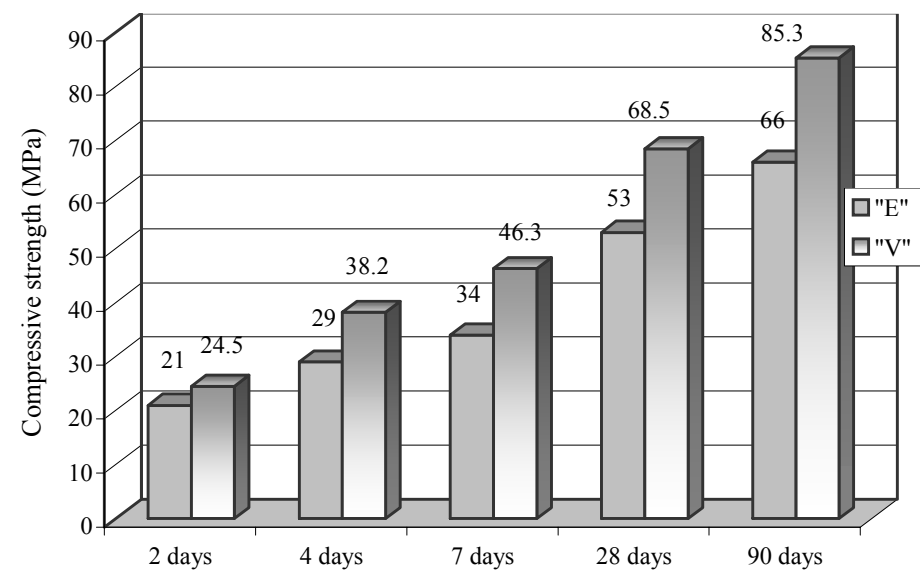

Fig. 4 Comparative review of compressive strength on both series "E" and "V"

\subsection{Research on concrete composites}

Research on concrete included mix design and proportion based on cement, silica fume and river aggregate separated in three fractions, steel fibers, as well as admixture type superplasticizer. Steel fibers bent on ends, dimensions 50x1.0 mm (aspect ratio 1/d = 50), produced by "Spajić", were used in these analyses, too. Silica fume was specified as "SikaFume HR/-TU", produced by "Sika", Switzerland. Admixture named "Viscocrete 5800 Multimix" from the same producer was applied. Cement marked as PC 20M (V-L) $42.5 \mathrm{R}$ "Lafarge" Beočin was used in this research.

Two concrete mixes (series marked as 1 and 2) with different quantities of cement (320 and $350 \mathrm{~kg} / \mathrm{m}^{3}$ ) were made. Quantity of silica fume amounted to less then $10 \%$ of cement mass and can be considered as constant (in mix 1-9.4\% and in mix 2-8.6\%). Quantities of aggregate were constant $\left(1900 \mathrm{~kg} / \mathrm{m}^{3}\right)$ as well as quantities of steel fibers $\left(25 \mathrm{~kg} / \mathrm{m}^{3}\right)$. Both mixes had fluid consistency, and the quantity of water was varied in 
order to sustain the same starting consistency according to the slump test $(12-13 \mathrm{~cm})$. Measured density of fresh concrete amounted to $2385 \mathrm{~kg} / \mathrm{m}^{3}$ (for mix 1) and $2450 \mathrm{~kg} / \mathrm{m}^{3}$ (for mix 2).

Compressive strength tests were performed on cube shaped $(20 \times 20 \times 20 \mathrm{~cm})$ specimens, 3, 7 and 28 days old, while the splitting tensile strength was measured only at 28 days old specimens (cylinder shaped specimens, $30 \mathrm{~cm}$ high and $15 \mathrm{~cm}$ in diameter). The results of the research of a subject, (represented by the average of three measurements) are shown in Table 3. The photograph given as Figure 5 shows the specimen after the splitting tensile test. The photograph shows that steel fibers continue to bridge the crack after the break.

Table 3 Overview of physical and mechanical properties of studied concrete

\begin{tabular}{|c|c|c|c|c|}
\hline \multirow{2}{*}{$\begin{array}{c}\text { Age } \\
\text { (days) }\end{array}$} & \multicolumn{2}{|c|}{$\begin{array}{c}\text { Compressive strength } \\
\mathrm{f}_{\mathrm{p}, \mathrm{sr}}(\mathrm{MPa})\end{array}$} & $\begin{array}{c}\text { Splitting tensile strength } \\
\mathrm{f}_{\mathrm{zc}, \mathrm{sr}}(\mathrm{MPa})\end{array}$ \\
\cline { 2 - 5 } & $\begin{array}{c}\text { Series } \\
" 1 "\end{array}$ & $\begin{array}{c}\text { Series } \\
\text { "2" }\end{array}$ & $\begin{array}{c}\text { Series } \\
\text { "1" }\end{array}$ & $\begin{array}{c}\text { Series } \\
\text { "2" }\end{array}$ \\
\hline 3 & 23,8 & 26,0 & - & - \\
7 & 34,9 & 36,7 & - & - \\
28 & 49,2 & 51,8 & 3,6 & 3,8 \\
\hline
\end{tabular}

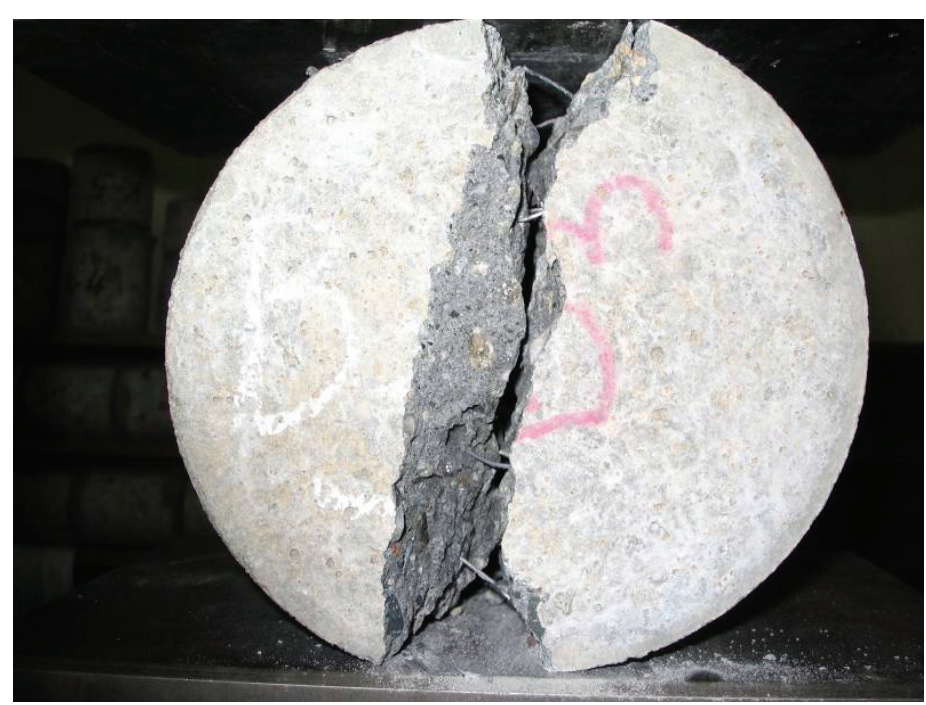

Fig. 5 Steel fibers continue to bridge the crack after the breakage of the specimen

As it can be seen from Figure 6, the fiber reinforcement of a cement-based matrix by using steel fibers contributes to the substantial improvement of toughness and ductility of concrete. As both of the two stress-strain diagrams are shown at the same coordinate system, it is obvious that the ductility of the composite - which could be defined as the 
surface between the $\sigma-\varepsilon$ line and $\mathrm{x}$-axis, in the case of fiber reinforced concrete (series II) greatly exceeds the ductility of the reference concrete (series I). The testing was conducted using the equipment for monitoring and acquisition of stress-strain data which was connected to the computer (as it can be seen on Fig. 7).

Testing of shear stress properties showed that in the case of fiber reinforced concrete great increase (app. 61\%) of this property appeared.

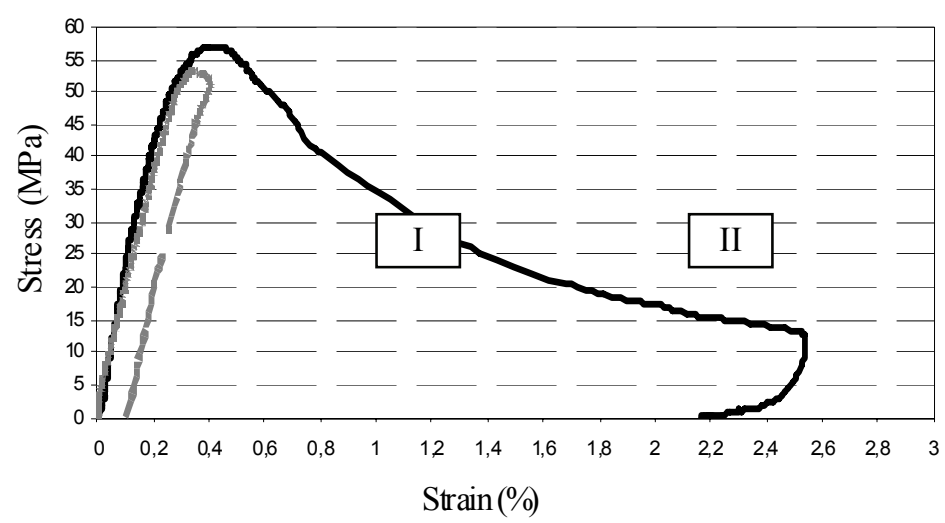

Fig. 6 Stress-strain diagrams of both series of concrete (I - reference and II - FRC)

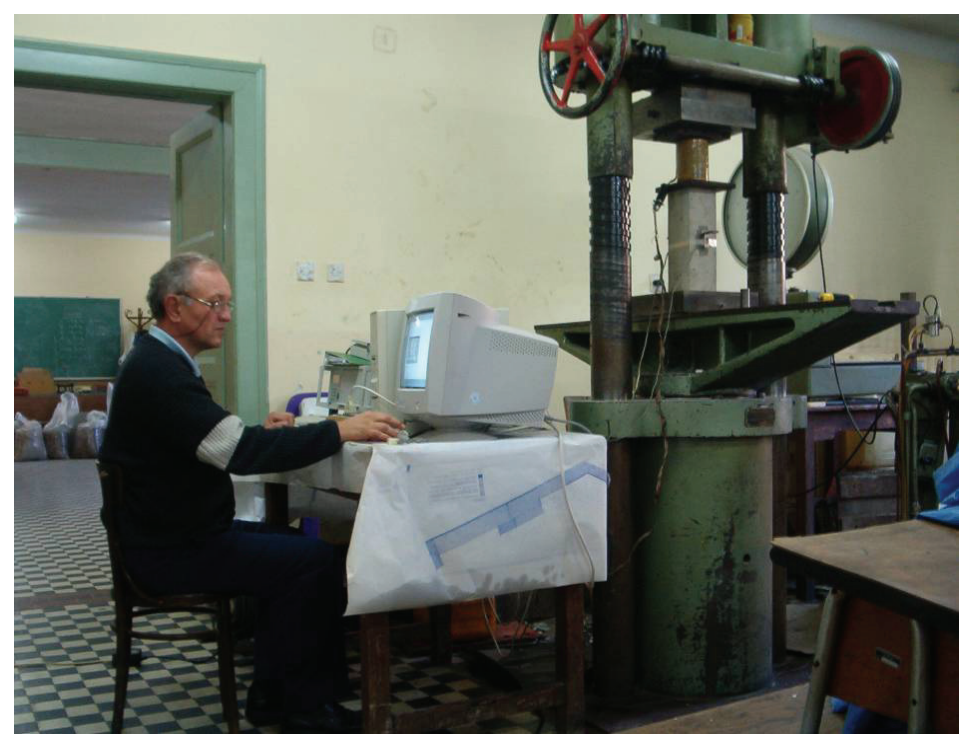

Fig. 7 Testing equipment for monitoring and aquisition of stress-strain data 


\section{CONCLUSIONS}

The presented results undoubtedly exhibit great improvement in mechanical properties for composites type mortar made with the addition of fiber-reinforcement ("V") in comparison to the reference mixture series ("E"). The addition of steel fibers in the amount of $60 \mathrm{~kg} / \mathrm{m}^{3}(0.45 \%$ of volume), combined with admixture type superplasticizer, gave higher strength, both flexural and compressive, at all ages. Better effects were observed in flexural strength tests (increase of 32-58\%), but the compressive strengths were significantly increased (increase of 17-36\%) as well. Table 2 gives a detailed overview of the results.

Based on the results of composites type concrete research, it can be concluded that the compressive strengths measured on specimens of series 1 and series 2 ( 28 days old) is approximately $50 \mathrm{MPa}$, which is achieved with relatively low quantities of cement (320 and $350 \mathrm{~kg} / \mathrm{m}^{3}$ ) and with the minimum addition of silica fume (app. 10\%). Given the pozzolanic effect of silica fume in concrete, further growth of strenght can be expected even after 28 days.

Splitting tensile strenght was measured after 28 days, and it amounted to $3.6 \mathrm{MPa}$ (for concrete 1) and 3.8 $\mathrm{MPa}$ (for concrete 2 ). This shows that with a relatively low percentage of steel fiber-reinforcement $\left(25 \mathrm{~kg} / \mathrm{m}^{3}\right)$ significant tensile strenght increment can be achieved; amounting to between $25-30 \%$ increase compared to the reference mixture specimens (without fiber reinforcement).

Testing of shear stress properties showed that in the case of fiber reinforced concrete great increase (app. 61\%) of this property appeared.

Due to high mechanical strenghts and presence of silica fume, these composites can be successfully used, both in new construction and in repairs and reconstruction of already existing structures. The use of steel fibre reinforced composites is recommended in particular for buildings where not only good physical and mechanical properties are required, but also high durability of materials used.

The obtained experimental results pointed to the significant improvement of mechanical and deformation properties of the composites with reinforcement.

\section{REFERENCES}

1. Jevtić, D., Zakić, D.; Analiza rezultata ispitivanja betona mikroarmiranog čeličnim vlaknima Spajić, Simpozijum JDGK, Vrnjačka banja, str. 321-326, 2004.

2. Muravljov, M., Jevtić, D., Zakić, D.; Primeri poboljšanja performansi betona i maltera putem mikroarmiranja, Godišnja konferencija "Savremeni problemi u građevinarstvu", Građevinski fakultet u Subotici, Subotica, str. 225-235, 2005.

3. Jevtić, D., Zakić, D., Markićević, J.; Uticaj mikroarmature na promenu fizičko-mehaničkih svojstava cementnih kompozita, Internacionalni naučno-stručni skup Građevinarstvo - nauka i praksa, Zbornik radova, Žabljak, str. 569-575, 2006.

4. Jevtić, D., Zakić, D.; Promena fizičko-mehaničkih svojstava maltera i betona mikroarmiranjem, 12. Kongres JDGK, Vrnjačka banja, str. 121-126, Knjiga 2, 2006.

5. Jevtić, D., Zakić, D.; Mikroarmirani malteri i betoni - mogućnost poboljšanja fizičko-mehaničkih svojstava, Materijali i konstrukcije 49 (2006), 3-4, str. 35-44.

6. Jevtić, D., Zakić, D., Savić, A.; Steel Fiber Reinforcement Analysis in Cement Composite Materials, Ist International Congress of Serbian Society of Mechanics, Kopaonik, 10.-13. April 2007., pp. 293-298.

7. The production catalogues of "Sika", Switzerland.

8. The production catalogues of "Spajić" fibers, Kobišnica, Serbia. 


\section{MODELIRANJE SVOJSTAVA MIKROARMIRANIH CEMENTNIH KOMPOZITA}

\section{Dragica Jevtić, Dimitrije Zakić, Aleksandar Savić}

U ovom radu su prikazani rezultati sopstvenih laboratorijskih ispitivanja u kojima se istražuje uticaj čeličnih vlakana kao mikroarmature na promenu svojstava cementnih kompozita tipa maltera $i$ betona. Ispitivane su mešavine - kompoziti tipa maltera koji su imali konstantan (identičan) sadržaj cementa, peska i silikatne prašine. Druga vrsta maltera - kompozita sadržala je $60 \mathrm{~kg} / \mathrm{m} 3$ čeličnih vlakana kao i jedan superplastifikator. Ispitivane su fizičko-mehaničke karakteristike kako mikroarmiranih maltera, tako i etalona (zapreminska masa, čvrstoća pri savijanju, čvrstoća pri pritisku). Ispitivanja na kompozitima tipa betona uključila su određivanje zapreminske mase, mehaničke čvrstoće i deformaciona svojstva. Ispitivanja su pokazala poboljšanje svojstava mikroarmiranih kompozita. 